\title{
Soil Classification and Potentiality Assessment for Some Rainfed Areas at West of Matrouh, Northwestern Coast of Egypt
}

\author{
Mohamed E. A. Khalifa and Nawal F. Beshay ${ }^{1}$
}

\begin{abstract}
Desert development is the key role of enhancing agricultural production in Egypt. The northwestern coast is one of the most attractive desert regions for sustainable agrarian development due to its abundant qualifications which have not sufficiently used yet. This investigation was carried out in El-Qasr - Um El-Rakham area as a model for rainfed pattern at the northwestern coast, to assess both of types and capability of the soils representing dominant land forms in the area. Studied area extends over about 159603 feddan including 12 drainage basins. The extent of landforms was spatially identified using geological and topographic maps in integration with DEM. The area represented by 6 main land forms; (1) Coastal plain $(\mathbf{1 7 . 8 \%})$ which include: Alluvial fans (9.1\%), Lagoonal depression and salt marsh (3.5\%), Oolitic longitudinal sand dunes $(2.2 \%)$ and Oolitic sand beach $(2.8 \%)$ - (2) Alluvial terraces and Interfluves wadis $(\mathbf{9 . 7 \%})$ - (3) Wadi course $(2.7 \%)$ - (4) Escarpment $(4.3 \%)$ - (5) Piedmont plain (13.6\%) - (6) Plateau $(52.1 \%)$ which include: Lower plateau (18.6\%) and Higher Libyan plateau $(33.5 \%)$.

Soils of the area were surveyed through 261 soil profiles which spatially distributed upon ETM+ LANDSAT 7 image classification to represent achieved landforms. Twenty four representative soil profiles were selected in this study. A digital vector database was created using GIS, consequently, soil and evaluation maps were generated. Results indicated that ten soil mapping units were differentiated according to differences in profile depth, texture and topography properties in the area under study. Further, data emphasized that $13.6 \%$ and $19.6 \%$ of the total area, respectively have deep and moderately deep profile depth. Coarse to moderately coarse texture classes dominated whole soils. Almost flat topography to gently undulated conquered the area over $69.3 \%$.
\end{abstract}

Based on field check and laboratory analysis, soils were classified into 10 family classes, while at sub great group level seven classes were differentiated. These are Typic Torrifluvents $(24259$ F $-15.2 \%)$, Typic Torripsamments (28728 F - 18.0\%), Lithic Torripsamments (36070 F - 22.6\%), Lithic Torriorthents (56978 F - 35.7\%), oolitic Torripsamments (7980 F - 5.0\%), Typic Aquisalids (5586 F - 3.5\%), and Typic Haplosalids (260 F -0.15\%). Soils of oolitic sand beach were classified as Oolitic Torripsamments, while soils of the lagoon depressions and salt marsh were classified as Typic Aquisalids. Soils of alluvial fans were classified as Typic Torrifluvents. As well, soils of the alluvial terraces and interfluves wadis, piedmont plain and wadi courses are generally belong to the subgroups Typic and lithic Torripsamments and Torriorthents, except small areas in the alluvial terraces and interfluves wadis and the lower portions of wadi courses were classified as Typic Torrifluvents and Typic Haplosalids. Generally, soils of plateau are classified as lithic Torriorthents.

The study concluded that, soil potentiality classified as "Good" over $13.6 \%$ of the area, including soils of alluvial fans, partially alluvial terraces and down streams of wadi courses landforms, where the potentiality index varied between 60.9 and $68.1 \%$. Meanwhile, the potentiality was classified as "Fair" on $19.6 \%$ of the area, representing some soils of alluvial fans, alluvial terraces, wadi middle streams and piedmont plain landforms, where the potentiality index ranged from 42.5 to $57.0 \%$. "Poor" potentiality unit extend over $22.6 \%$ of the area occupying some soils of alluvial terraces, wadi upper streams and piedmont plain landforms, as the potentiality index ranged from 30.5 to $36.8 \%$. Potentiality indices ranged between $1.2-11.5 \%$ indicating "Very poor" and "Non agricultural" units over the rest of the area, which may be relevant to other land utilization types. Low soil potentiality associated with limitations related to; limited soil profile depth, poor drainage, coarse texture, low clay content, high salinity, high lime content and low fertility status.

Key words: northwest coast, rainfed agriculture, landforms, soil classification, land potentiality.

\section{INTRODUCTION}

Reclamation of desert lands is one of the most important strategic initiatives in Egypt. In this light, the national interest of desert development became greater to release high population pressure on cultivated land. Significant efforts have been devoted to the proper management of the desert regions (Ismail et. al., 1986). However, limited water resources affect the agrarian development in the desert environments, therefore, alternatives sources of water have to be considered.

Among the most promising lands for agricultural expansion beyond the Nile Delta and Valley are the soils of the northwestern coastal region. In this light, the agriculture development in the northwestern coastal region using rainfed systems became one of the most important incomes in the area. At present, northwestern coastal zone of Egypt is enjoying more attention for future sustainable development (Shaaban, 2010). Future

\footnotetext{
${ }^{1}$ Pedology Dept., Water Resources and Desert Land Division, Desert Research Center, Egypt.

Received November 17, 2015, Accepted December 2, 2015
} 
of agricultural expansion in the region demands that all soil resources should be carefully studied and appraised with the aim of estimating their potentialities, (Abd ElRahman et. al., 1986).

Calcareous type of soil predominates such region, where only few thousands out of about 2-3 million acres are cultivated mainly under the dry farming agricultural systems. Rainfed areas depend on the scanty winter rainfall and in limited areas on supplemental irrigation with rather saline water of shallow wells (Abdel-Kader, et. al., 1994, 2002 and 2004). From Pedology point of view, Abd El-Rahman et al. (1986 \& 1987) carried out a regional soil and land capability maps of the northwestern coastal region. It is concluded that soils of the region were found to be very much associated with the types and locations of the defined geomorphic units. Further, about $35-40 \%$ of the soils were marginal to moderate suitable for agricultural land utilization practices. Khalifa (2013) have used terrain analysis to prove that soils of the northwestern drainage basins were formed according to topography. During the last 10 years, Desert Research Center staff (DRC staff, 2007 -2015 ) investigated a variety of comprehensive studies for integrated development of some selected watershed basins located mainly west of Matrouh.

El-Qasr - Um El-Rakham area represents the catchment basins of twelve drainage patterns located west of Matrouh city at the northwestern coast of Egypt. That area receives appreciable amounts of rainwater runoff during rainy periods. This study is a trial to shed more lights on the soils associated with the different landforms at this area. Soil classification, types, and capabilities were investigated for agricultural expansion. It is hopefully that present study could be useful as a sound basis for agriculture development of the area under consideration.

\section{MATERIALS AND METHODS}

\section{1- Physiographic features of the studied area:}

Studied area is located west of Mersa Matrouh at the northwestern coastal region of Egypt between ElQasr and Um El-Rakham areas. It occupies an area of about 159,603 feddan representing the catchment basins of twelve drainage lines namely from east to west; Kharouba, Raml, Medwer, Majed, Washka, Sanab, Um Moshtan, Jowidate, Habes, Um El-Rakham, Ageeba, and Abu Lahu. The area is bounded by latitudes $31^{\circ} 09^{\prime}-31^{\circ} 26^{\prime} \mathrm{N}$ and longitudes $26^{\circ} 56^{\prime}$ $27^{\circ} 14^{\prime} \mathrm{E}$ as seen in map (1).

Considered region is one of the mildest over Mediterranean zone. Its climate is characterized by long hot dry summer and short cool rainy winter typical of sub-arid region, defined as "Arid Mediterranean". In general, monthly temperature varied between 14.4 and $26.8{ }^{\circ} \mathrm{C}$, wind speed averaged at $18.9 \mathrm{~km} / \mathrm{hr}$, and the average annual rainfall ranged from 100 to $190 \mathrm{~mm}$ (DRC staff, 2010). According to the limits outlined by Soil Survey Staff (2010), soils are characterized by torric moisture and hyperthermic temperature regimes.

Lithologically, area under investigation is dominated by a sedimentary succession ranging from Tertiary period (Middle Miocene) to Quaternary. Middle Miocene sediments are widely spread in the table land. Quaternary deposits are differentiated into Pleistocene and Holocene formations. They have wide distribution and constitute the bulk of the coastal plain (El-Shazely et. al., 1975). For details, area between the present shoreline and Libyan plateau is mostly constituted of calcareous Pliocene and Pleistocene formations and covered by Recent deposits (Shata, 1971).

The main source of irrigation water in the area is rainfall. Rain distribution along the coastal zone is not even. The amount of rainfall shows steady decrease in the inland direction where it reaches about $50 \mathrm{~mm}$ at the southern limit of the catchment zone (FAO, 1970). Consequently, deep wadis found in the area cutting the table land and drain its water towards the northern coastal plain. Temporary surface run off occurs immediately after rainy periods and represents a definite percentage of the rainfall. Water run off differs from one locality to another depending on some factors such as slope, topography, nature of cap rock, field water capacity and the catchment area. Therefore, water harvesting systems are applied through the construction of soily, cemented and/or stony dykes established between different levels along the streams. In limited areas, supplemental irrigation with shallow well water is used (DRC, 2010).

The region is mainly characterized by different features namely; 1) Southern table land, characterized by an uniform relief and shallow rocky soils; 2) Escarpment of table land, characterized by a rough relief and occurrence of barren rocks; 3) Coastal plain, consists of alluvial fans, beach ridges, inland dunes and depressions of the drainage channels; 4) Littoral belt, consists of lagoons and salt marshes; 5) Wind blown sand accumulated in different forms of sand sheets, dunes and hummocks (Abu El-Izz, 1971). Considered area could be characterized as a coastal plain bounded inland by first escarpment of the northern elevated plateau as a part of Marmarica formation belonging to Lybian Plateau.

Ecologically, many natural plants were recorded in wadis differing in their type, economical use and palatability for animals. They include pereminal and 
annual species as well as various range aromatic and medicinal types (DRC, 2014).

\section{2- Soil mapping using image classification and GIS processing:}

A LANDSAT 7 ETM+ scene captured in 2014 representing the study area was cropped, rectified, and geometrically corrected by IMAGINE 8.6 (2001). Produced image was spectrally classified using the unsupervised classification. Ten spectral classes were achieved defining the ground surface as shown in map (2). Digitized data from physiographic maps (1:50000) concerning topography include contour lines and spot heights. They were transformed into digital girded raster DEM as shown in map (3) by using Inverse Distance Weighted Average (IDWA) interpolation method (ESRI, 2006). The information listed at the geological map (EGPC, 1988) integrated with created DEM to differentiate several dominated landforms in the area in which observation sites were spatially distributed. Further, created DEM used to delineate the watershed drainage system concerning both of wadi course and basin borders (map 4). A digital vector database for the study area was created using Arc-GIS 9.2 (ESRI, 2006) software. Locations, areas and longest flow length of the studied watershed basins are shown in table (1). Locations of soil observations were digitized, as a unique identifier for each location linked to associated attribute data using the Database Management System (DBMS). Soil mapping units were created by overlapping the most variable soil data. Final soil and evaluation maps were generated.

\section{3- Field work and laboratory analysis:}

Soils of the studied area were surveyed through 261 soil profiles. From which, 24 were selected to represent the present landforms and the associated different soilmapping units. Detailed morphological descriptions of these soil profiles were recorded on the basis of guidelines for soil description, FAO (2006). According to required data input for applied land evaluation model the collected soil samples were subjected to physical, chemical and fertility analyses. Soil laboratory analyses performed according to Page et al, (1982) such as soil texture, total carbonates, electrical conductivity of soil paste extracts (EC), soil reaction $(\mathrm{pH})$, and total nitrogen. While organic carbon content was determined according to Jackson, (1973).

Soils were evaluated using Parametric Land Evaluation System (PLES - Khalifa, 2004), after some modification of ratting gradients as listed by Sys et. al. $(1991$ - I). As well, the guidelines listed by FAO (1983) for rainfed agriculture. Evaluated soil properties in the current study include physical (P.I), chemical (C.I) and fertility properties (F.I). The final index of land evaluation (F.I.L.E) described as percentage to characterize the land potentiality of the area according to the following equation:

$$
F . I . L . E .=\frac{3}{\frac{1}{P . I}+\frac{1}{C \cdot I}+\frac{1}{F \cdot I}}
$$

Land potentiality was achieved by classifying the land under study into classes of productivity based on the final index value of land evaluation as shown in table (2).

\section{RESULTS AND DISCUSSION}

El-Qasr -Um El-Rakham area covers a wide range of altitudes varying from zero level to $200 \mathrm{~m}$ a.s.l. encompassing ten landform units. Areas and the spatial distribution of predominant landform units are shown in table (3) and map (5), respectively. Soil observations were distributed among achieved landforms with respect to studied basins as seen in table (4) and map (6). Some morphological, physical, and chemical properties of the studied soil profiles are set out in table (5) and classified according to Soil Survey Staff (S.S.S, 2010) as shown in table (6) and map (7). Based on the variations in profile depth, texture and topography the main soil mapping units in the area are delineated, (map 8). The main landform units and associated different soil types can be discussed as following:

\section{Soils of oolitic sand beach (OSB) and longitudinal sand dunes (OSD)}

These units occupy about 7980 feddan $(5.0 \%)$ in the coastal part of the area. Sediments of these landforms formed of white oolitic carbonates deposited under marine environmental conditions. Recognized soil type in the sand beach is shallow to deep oolitic coarse textured soils with almost flat topography (pedon 77). Soils have loose oolitic coarse sand throughout, carbonatic $\left(\mathrm{CaCO}_{3}\right.$ from 45 to $\left.60 \%\right)$, moderately alkaline ( $\mathrm{pH}$ range between 8.1 and 8.3 ), and extremely affected with salts (EC vary from 6.8 to $18.4 \mathrm{dSm}^{-1}$ ). Effective soil depth is deep in general and sometimes being shallow due to water table limitation. On family level, recognized soil Taxonomic unit is Carbonatic, hyperthermic; oolitic Torripsamments. (Harga and Rabie, 1974).

\section{Soils of lagoon depressions and salt marshes (LGSM)}

These landforms are formed under lacustrine conditions and located as scattered patches in the coastal part over about 5586 feddan (3.5\%). Dominant soil type is shallow to deep, medium to coarse - textured soils with interlayering salts and almost flat topography (pedon 183). 

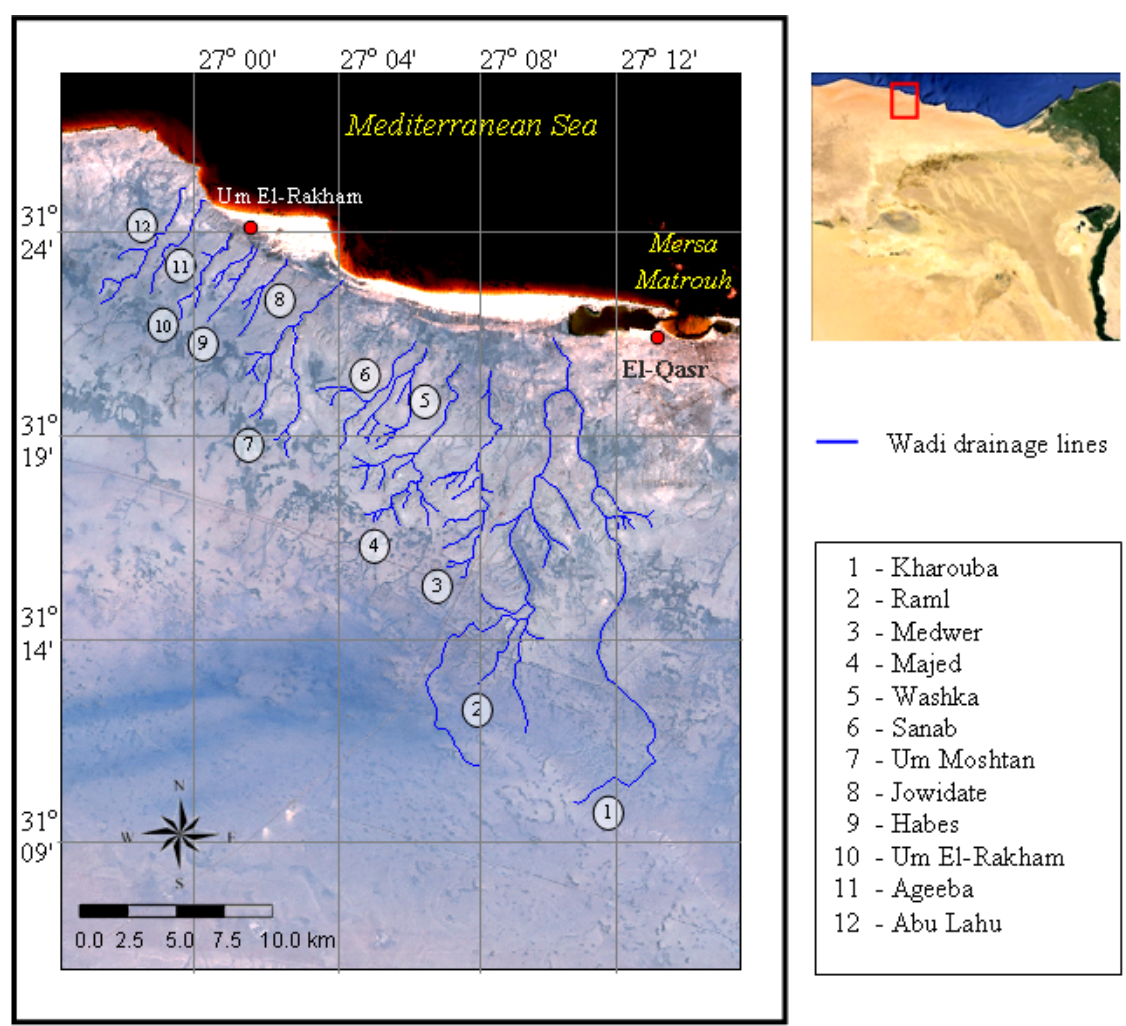

— Wadi drainage lines

1 - Kharouba

2 - Raml

3 - Medwer

4 - Majed

5 - Washka

6 - Sanab

7 - Um Moshtan

8 - Jowidate

9 - Habes

10 - Um El-Rakham

11 - Ageeba

12 - Abu Lahu

Map 1. Location of the studied area at west or Matrouh.
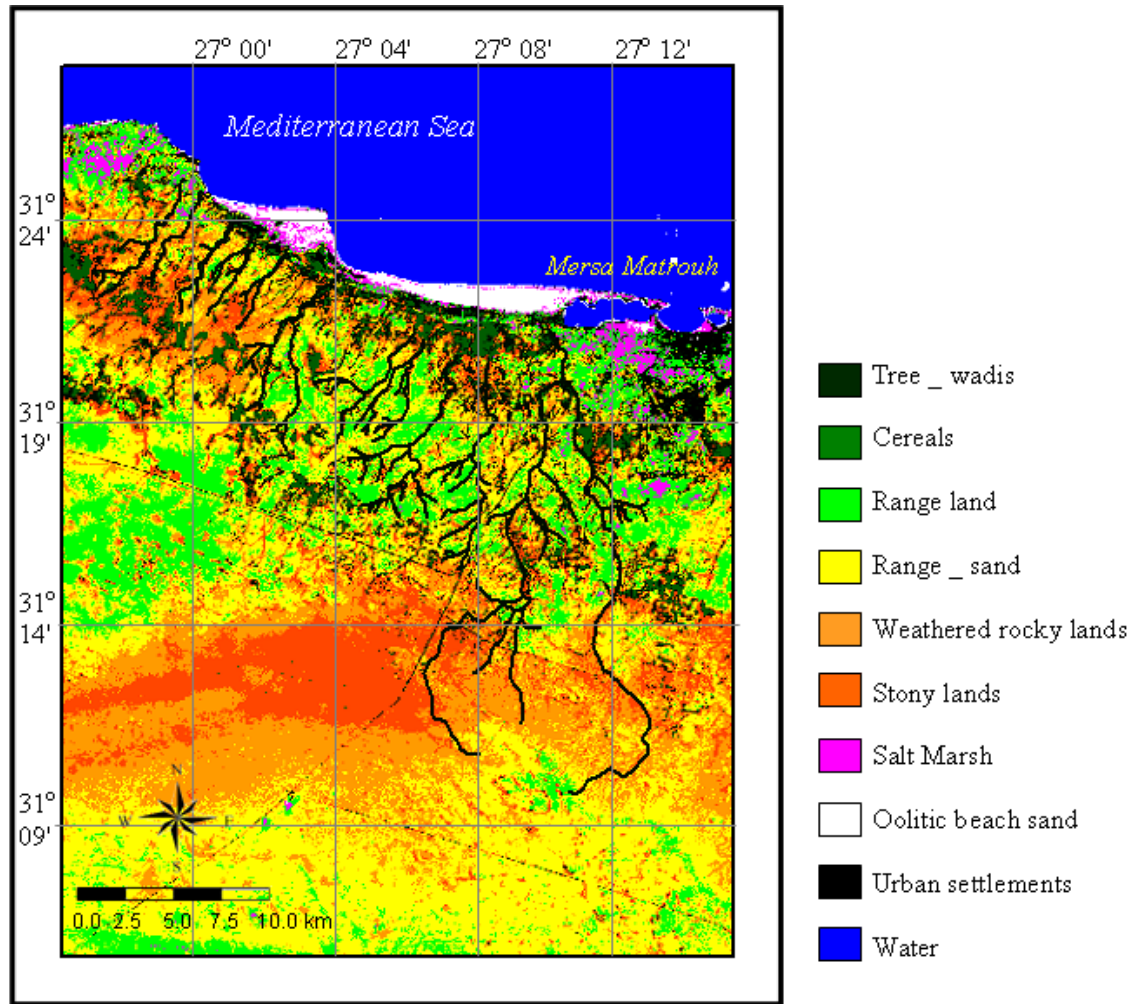

Map 2. Spectral land cover calssification of the studied area. 

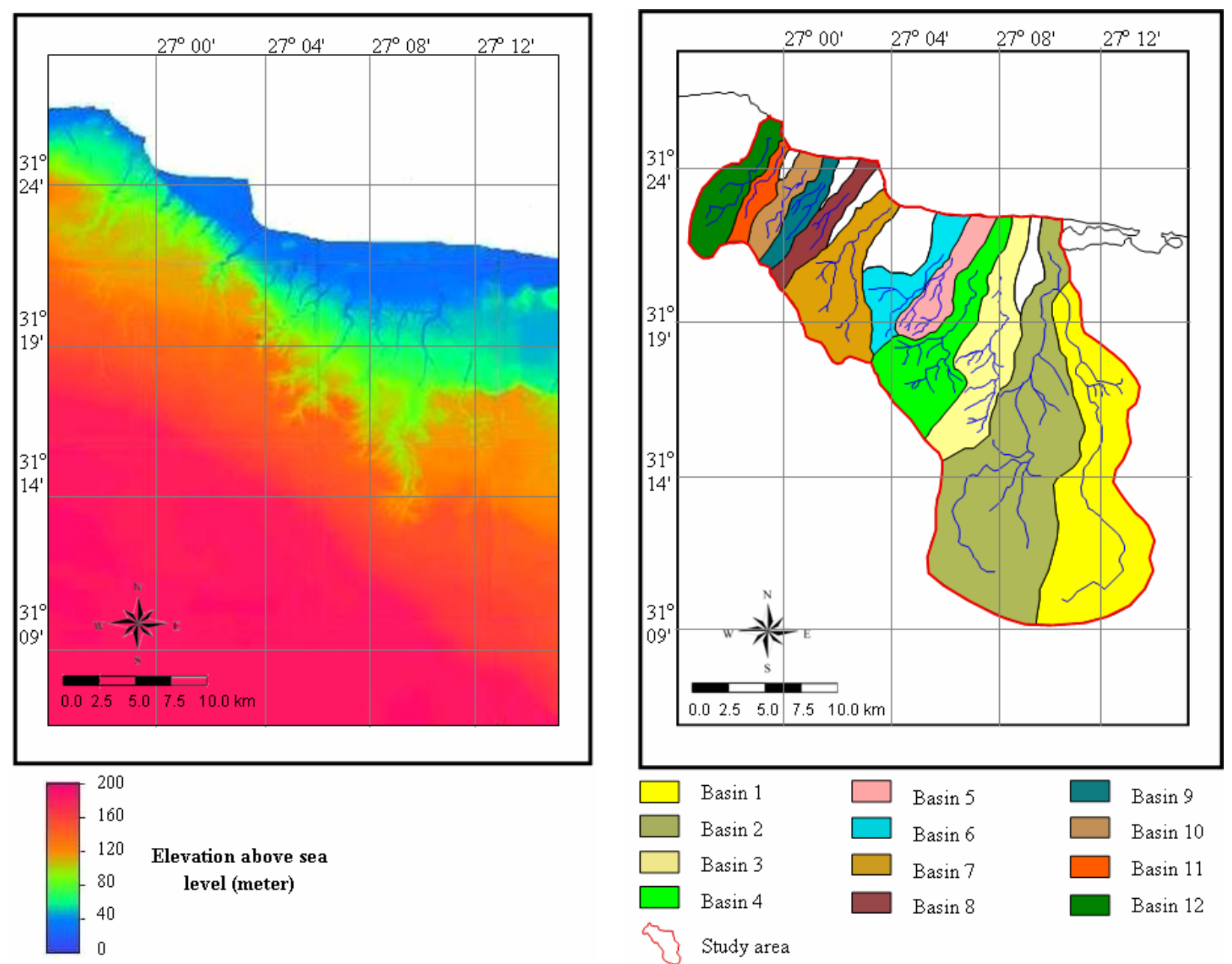

Map 3. Digital Elevation Model (DEM) of the studied area.

Map 4. Watershed basins in the studied area.

Table 1. Locations, areas and longest flow length of the studied watershed basins

\begin{tabular}{lcccc}
\hline \multirow{2}{*}{ Watershed Basin } & \multirow{2}{*}{ Longest Flow Length (m) } & Center of catchment area & \multicolumn{2}{c}{ Area } \\
\cline { 4 - 5 } & & Lat. (N), Long. (E) & Feddan & \% \\
\hline Kharouba & 23450 & 3455962,518299 & 39396 & 24.7 \\
\hline Raml & 26240 & 3458974,515988 & 50381 & 31.6 \\
\hline Medwer & 13600 & 3463315,512837 & 16320 & 10.2 \\
\hline Majed & 14250 & 3464576,510246 & 13680 & 8.6 \\
\hline Washka & 8740 & 3467657,510176 & 5244 & 3.3 \\
\hline Sanab & 9150 & 3467027,508005 & 6149 & 3.9 \\
\hline Um Moshtan & 12500 & 3468988,504293 & 9000 & 5.6 \\
\hline Jowidate & 7400 & 3470879,503103 & 3552 & 2.2 \\
\hline Habes & 6200 & 3471929,501772 & 2678 & 1.7 \\
\hline Um El-Rakham & 7350 & 3472069,500512 & 2999 & 1.9 \\
\hline Ageeba & 7200 & 3472839,499461 & 2765 & 1.7 \\
\hline Abu Lahu & 12400 & 3473189,497851 & 7440 & 4.7 \\
\hline Total & & & 159603 & 100 \\
\hline
\end{tabular}


Table 2. Land potentiality classification according to PLES

\begin{tabular}{cccc}
\hline Potentiality class & Intensity of limitation & Land Potentiality Class & F.I.L.E (\%) \\
\hline P1 & No & Excellent & $100-80$ \\
P2 & Slight & Good & $79-60$ \\
P3 & Moderate & Fair & $59-40$ \\
P4 & Sever & Poor & $39-20$ \\
P5 & Very sever & Very poor & $19-10$ \\
P6 & Extremely sever & Non-agricultural & $<10$ \\
\hline
\end{tabular}

Table 3. Landform units in the studied area

\begin{tabular}{cllcc}
\hline No & $\begin{array}{c}\text { Main Landform } \\
\text { Units }\end{array}$ & \multicolumn{1}{c}{ Sub Landform Mapping Units } & Symbol & Area \% \\
\hline 1 & Coastal Plain & Oolitic sand beach & OSB & 2.8 \\
\cline { 3 - 5 } & & Oolitic longitudinal sand dunes & OSD & 2.2 \\
\cline { 3 - 5 } & & Lagoonal depression and salt marsh & LGSM & 3.5 \\
\cline { 3 - 5 } & Alluvial fans & AFN & 9.1 \\
\hline \multicolumn{2}{l}{ Alluvial Terraces and Interfluves Wadis } & AT-IW & 9.7 \\
\hline 3 & Wadi Course & WCRS & 2.7 \\
\hline 4 & Escarpment & ESC & 4.3 \\
\hline 5 & Piedmont Plain & PDP & 13.6 \\
\hline 6 & Plateau & Lower table plateau & LPL & 18.6 \\
\cline { 3 - 5 } & & Libyan higher plateau & HPL & 33.5 \\
\hline
\end{tabular}

Table 4. Distributions of soil profiles within recognized landforms referring to catchment basins

\begin{tabular}{|c|c|c|c|c|c|c|c|c|c|c|c|c|c|}
\hline Basin & 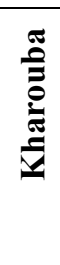 & $\begin{array}{l}\bar{\Xi} \\
\tilde{\Xi}\end{array}$ & 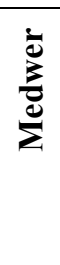 & $\frac{\bar{\sigma}}{\tilde{\sigma}}$ & $\begin{array}{l}\frac{\pi}{4} \\
\frac{\pi}{5} \\
\frac{\pi}{3}\end{array}$ & 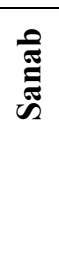 & 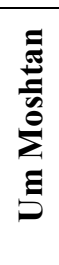 & & 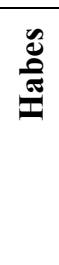 & 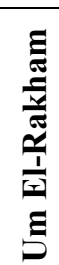 & 芯 & 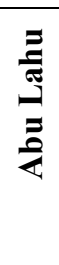 & $\stackrel{\bar{\pi}}{\theta}$ \\
\hline Sand beach & & & & & & & 1 & & & & & 1 & 2 \\
\hline Lagoonal salt marsh & & & & & & & & 1 & & & & & 1 \\
\hline Alluvial fans & 7 & 6 & 5 & 4 & 3 & 6 & 4 & 2 & 2 & 2 & 1 & 4 & 46 \\
\hline Alluvial terraces & 6 & 14 & 6 & 5 & 8 & 7 & 7 & 4 & 4 & 5 & 7 & 8 & 81 \\
\hline Wadi course & 2 & 3 & 2 & 1 & 3 & 2 & 2 & & 2 & 2 & & 2 & 21 \\
\hline Piedmont plain & 3 & 7 & 4 & 10 & 2 & 5 & 19 & 7 & 4 & 5 & 4 & 7 & 77 \\
\hline Lower plateau & 7 & 12 & 4 & & & & & & & & & & 23 \\
\hline Higher plateau & 2 & 8 & & & & & & & & & & & 10 \\
\hline Total & 27 & 50 & 21 & 20 & 16 & 20 & 33 & 14 & 12 & 14 & 12 & 22 & 261 \\
\hline
\end{tabular}

Soil material varies in both of texture from sand to loam and the effective depth from deep to shallow. Soils sometimes were saturated with saline water as salts accumulated throughout the profile horizons. Salt percentage and horizon thickness in these soils are identified as Salic horizon. (Soil Survey Staff, 2010). Accordingly, these soils are classified on the family level as Coarse loamy, calcareous, hyperthermic; Typic Aquisalids.

\section{Soils of alluvial fans (AFN)}

This unit extends over about 14524 feddan $(9.1 \%)$ to the south following the coastal line. It is mainly resulted from the coalescence of alluvial fans which were

formed through deposition of fines through drainage lines. The landscape is almost flat to gently undulating with a slope of less than $1 \%$. Natural vegetation is dense, removed in some sites for cultivation of olives, figs, wheat, barely, and vegetables. Main soil types of this unit are; (1) Deep moderately coarse to coarsetextured soils, sometimes with finer surface or substratum and almost flat to gently undulating topography, (pedons 136, 8) - (2) Deep coarse textured soils with almost flat to gently undulated topography, (pedon 19) - (3) Moderately deep moderately coarse to coarse - textured soils with almost flat to gently undulating topography, (pedon 82). 


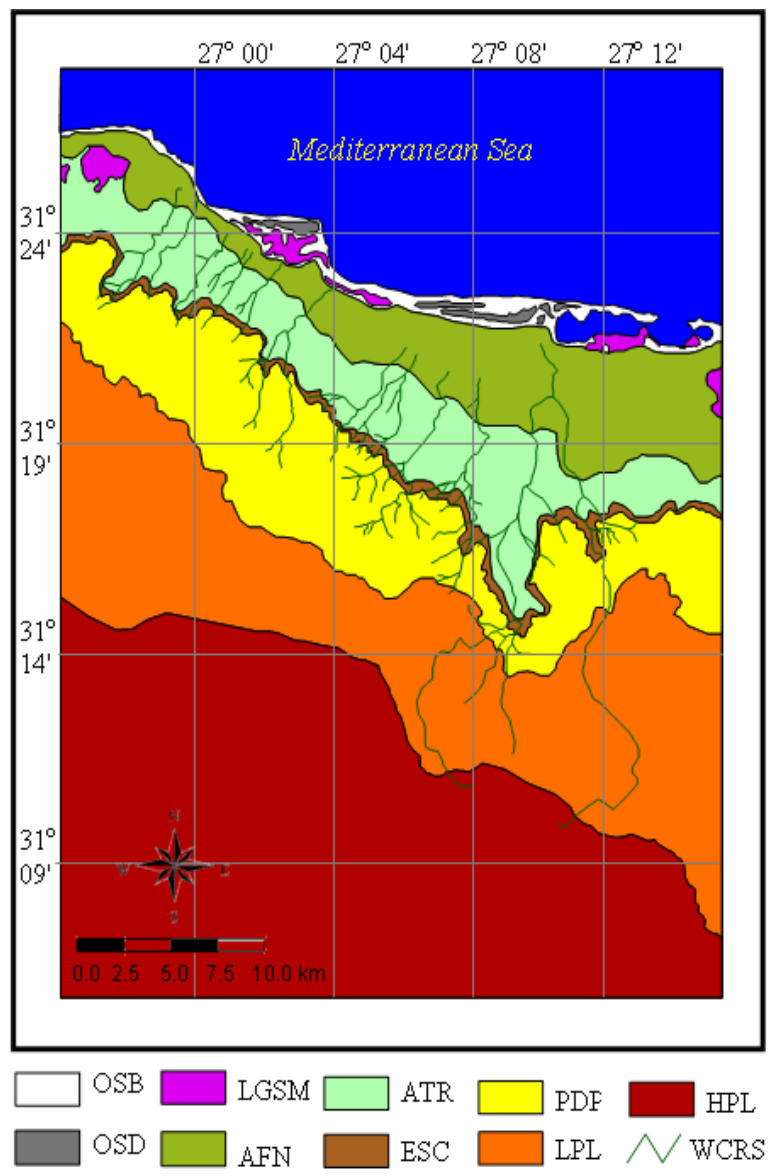

\section{Map 5. Landform Mapping Units in the studied area.}

Results show that soil effective depth is deep to moderately deep underlined by limestone bedrock. Soil materials are formed of alternating layers of SCL, SL and / or LS mixed with few fine gravels $(<7.2 \%)$. Carbonates are found either in segregated or unsegregated forms, where $\mathrm{CaCO}_{3}$ ranged between $14.79-32.5 \%$. pH values (7.8-9.1) indicate a moderately to strongly alkaline reaction. Soil salinity generally is slightly saline as EC varied from 0.303 to $7.0 \mathrm{dS} \mathrm{m}^{-1}$. Organic carbon percentage is low $(1.15-$ $0.221 \%$ ) and decreases with depth. The majority of soils are classified as fluvents where the sedimentary environment is mainly alluvial and its organic carbon decrease with depth, while other ones were classified as psamments. Further, soils were classified at the family levels as (a) Coarse loamy, calcareous, hyperthermic; Typic Torrifluvents (pedons 8 \& 82) - (b) Calcareous, hyperthermic; Typic Torripsamments (pedon 19) - (c) Fine loamy, calcareous, hyperthermic; Typic Torrifluvents (pedon136).

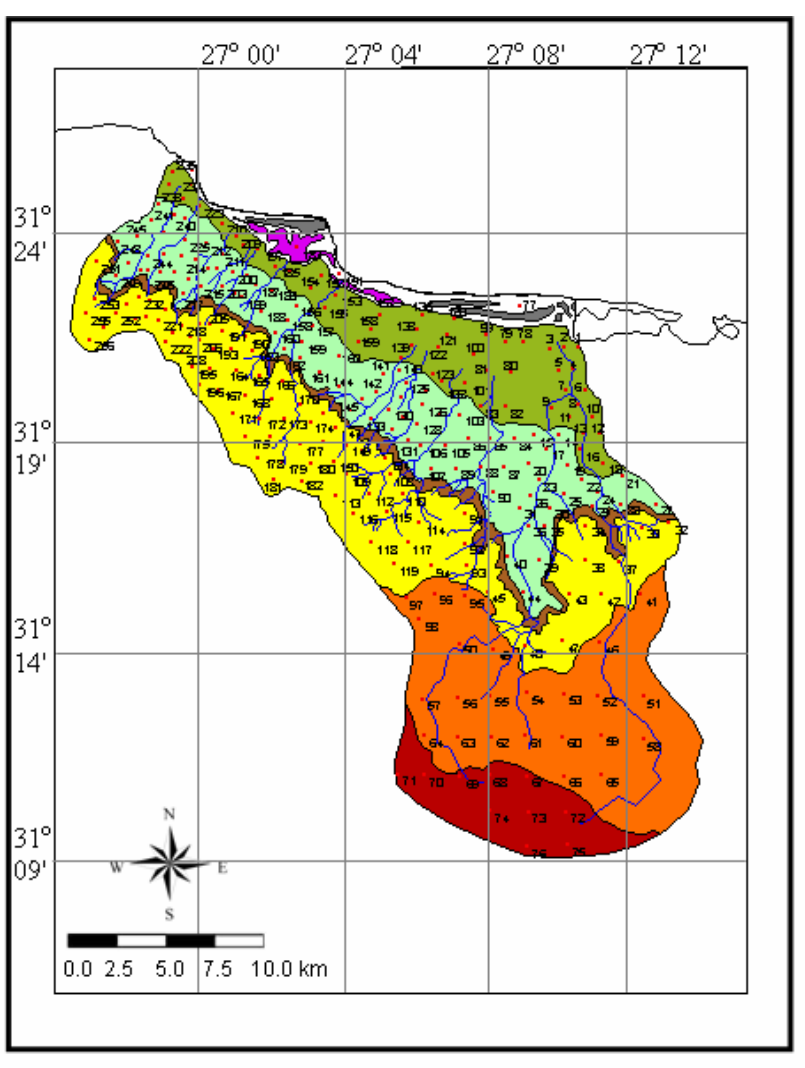

- Profile location - Wadi drainage lines

\section{Map 6. Locations of 261 studied soil profiles distributed over main landforms.}

Soils of alluvial terraces and interfluves wadis (ATIW)

These soils cover an area of about 15482 feddan (9.7\%), adjacent to the main channels separating them and their tributaries. Their landscape is almost flat to gently undulating, developed into conspicuous terraces in places. Gravelly - sized limestone fragments forming the desert pavement and covering the land surface. Natural vegetation is scanty or absent. Soil profiles vary widely in their effective depth from very shallow to deep, texture from coarse to moderately coarse changed to more fines at some places and salinity varies from slightly to extremely saline (EC from 0.6 to $32.3 \mathrm{dS} \mathrm{m}^{-1}$ ). Soils generally are slightly to moderately alkaline ( $\mathrm{pH}$ varied between 7.25 and 8.3), and being strongly calcareous as values of $\mathrm{CaCO}_{3}$ varied from 15.58 to $35.7 \%$.

In terms of soil depth, texture, and topography five soil types are recognized; (1) Deep moderately coarse to coarse- textured soils, sometimes with finer surface or 
substratum and almost flat to gently undulating topography, (pedon 43) - (2) Deep coarse textured soils with almost flat to gently undulated topography, (pedon 241) - (3) Moderately deep moderately coarse to coarse - textured soils with almost flat to gently undulating topography, (pedons 261, 32) - (4) Shallow moderately coarse to course - textured soils with almost flat to undulating topography, (pedon 212) - (5) Very shallow coarse - textured soils with almost flat to gently undulating topography, (pedon 245).

These soils are formed from recent water or wind deposited sediments or of recent eroded surfaces and lack any evidence of development, which qualify them to be classified under the Entisol order. The following soil families were concluded: (a) Calcareous, hyperthermic; Typic Torripsamments (pedons 241, 261) - (b) Coarse loamy, calcareous, hyperthermic; Typic Torrifluvents (pedons 32) - (c) Fine loamy, calcareous, hyperthermic; Typic Torrifluvents (pedon 43) - (d) Calcareous, hyperthermic; Lithic Torripsamments (pedon 212) - (e) Sandy, calcareous, hyperthermic; Lithic Torriorthents (pedon 245).

\section{Soils of wadi courses (WCRS)}

Land form of wadi courses represents the narrow streams and doesn't exceed 2.7\% (4309 feddan) of the studied area. Drains start cutting the upper calcareous plateau in which soils formed over eroded limestone. Sediments moved downward along the stream and forming soils with ascended profile depths. Soils have dense vegetation cover and cultivated with rainfed olive, figs, barley and wheat. Soils vary in their properties according to stream location. Accordingly, four soil types dominate this unit, namely: (1) Deep moderately coarse to coarse - textured soils with almost flat to gently undulating topography (pedons 127, 100, 31 ) - (2) Moderately deep moderately coarse to coarse textured soils, with almost flat to gently undulating topography (pedon 33) - (3) Shallow coarse textured soils with gently undulated topography (pedon 150) (4) Very shallow coarse textured soils with undulated topography (pedons 205, 179).

Soils formed on middle and upper streams, mostly characterized by a rocky or very shallow to shallow soil depth, sandy texture and rough relief. On the family level, they are classified as (a) Sandy, calcareous, hyperthermic; Lithic Torriorthents (pedons 179, 205) (b) Calcareous, hyperthermic; Lithic Torripsamments (pedon 150). Contrarily, soils in the downstream areas, mostly characterized by a uniform relief and deep to moderate deep profiles. Based on soil characteristic differences and soil profile development, three family levels are recognized: (a) Soils have sandy loam texture within the profile control section, strongly saline, and have a surface salic horizon or within $40-75 \mathrm{~cm}$ from the soil surface are classified as Coarse loamy, calcareous, hyperthermic; Typic Haplosalids ( pedons $127 \& 31$ ) - (b) Soils have sandy texture, non-saline and more than $40 \%$ carbonate content within the profile control section are classified as Carbonatic, hyperthermic; Typic Torripsamments (pedon 33) - (c) Soils have non-uniform layers of texture (LS/SCL), non-saline, strongly calcareous $\left(\mathrm{CaCO}_{3}\right.$ ranged from 16.72- 22.18\%), low O.M percentage increasing with depth, and lack any evidence of profile development are classified as Coarse loamy, calcareous, hyperthermic; Typic Torrifluvents (pedon 100)

\section{Soils of piedmont plain (PDP)}

Piedmont plain stretched over 21706 feddan (13.6\%) occupying a southern part of the study area adjacent to the plateau and its escarpment. Landscape is undulating, dissected by many dry gullies and wadis, barren from natural vegetation, and covered by gravels and boulders. Soils are very shallow to moderately deep due to the prevailing destructive erosion forces caused by both water and wind. On basis of soil depth, texture and topography three soil types are identified namely; (1) Moderately deep coarse - textured soils with gently undulated topography (pedon 115) - (2) Shallow moderately coarse to coarse - textured soils with almost flat to undulated topography (pedon 173) - (3) Very shallow coarse - textured soils with undulated topography (pedon 192).

Collected data and analytical results indicate that soil profiles are moderately deep to very shallow limited by limestone bedrock. Soils mostly are sandy, moderately alkaline ( $\mathrm{pH}$ ranged between $7.8-8.3$ ), slightly to moderately affected with salts (EC varied from 2.5 to $8.5 \mathrm{dS} \mathrm{m}-1)$, and highly calcareous $\left(\mathrm{CaCO}_{3}\right.$ values were between 22.4 - 35.7\%). According to Soil Survey Staff (2010), three family levels could be defined; (a) Calcareous, hyperthermic; Typic Torripsamments, (pedon 115) - (b) Coarse loamy, calcareous, hyperthermic; Lithic Torriorthents (pedon 173) - (c) Sandy, calcareous, hyperthermic; Lithic Torriorthents (pedon 192)

\section{Soils of the plateau (PL)}

It occupies the extreme southern portion forming the wildest landform of the study area over about 83153 feddan $(52.1 \%)$. Ground elevation ranges between 120 and $200 \mathrm{~m}$ a. s. 1. encompassing two main districts namely lower plateau and Libyan higher plateau. Surface is almost flat to gently undulating covered by desert pavement. Soils are mainly pseudo-rocky with few natural vegetation, except areas that are covered by alluvial deposits or sand sheets. 


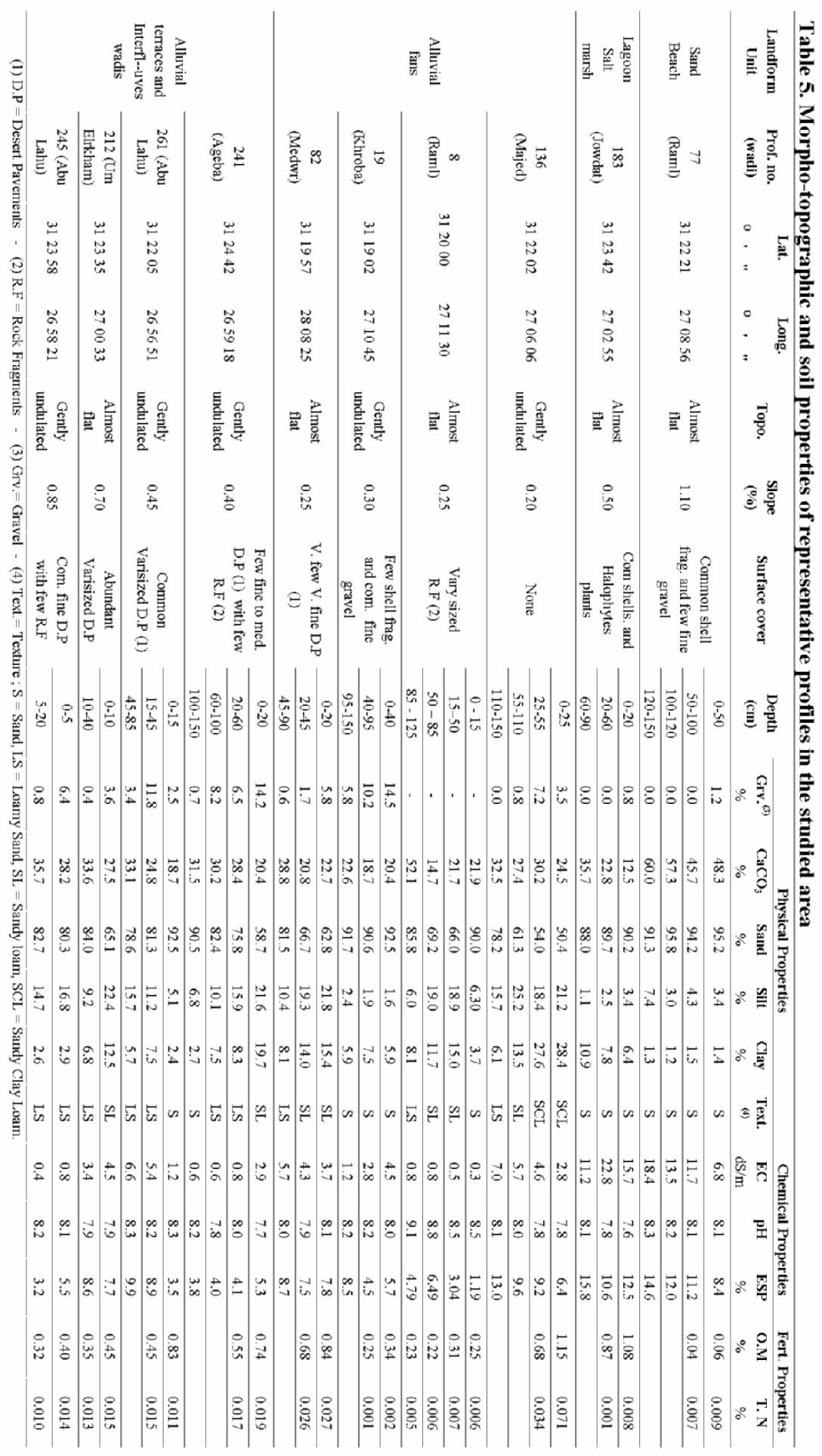




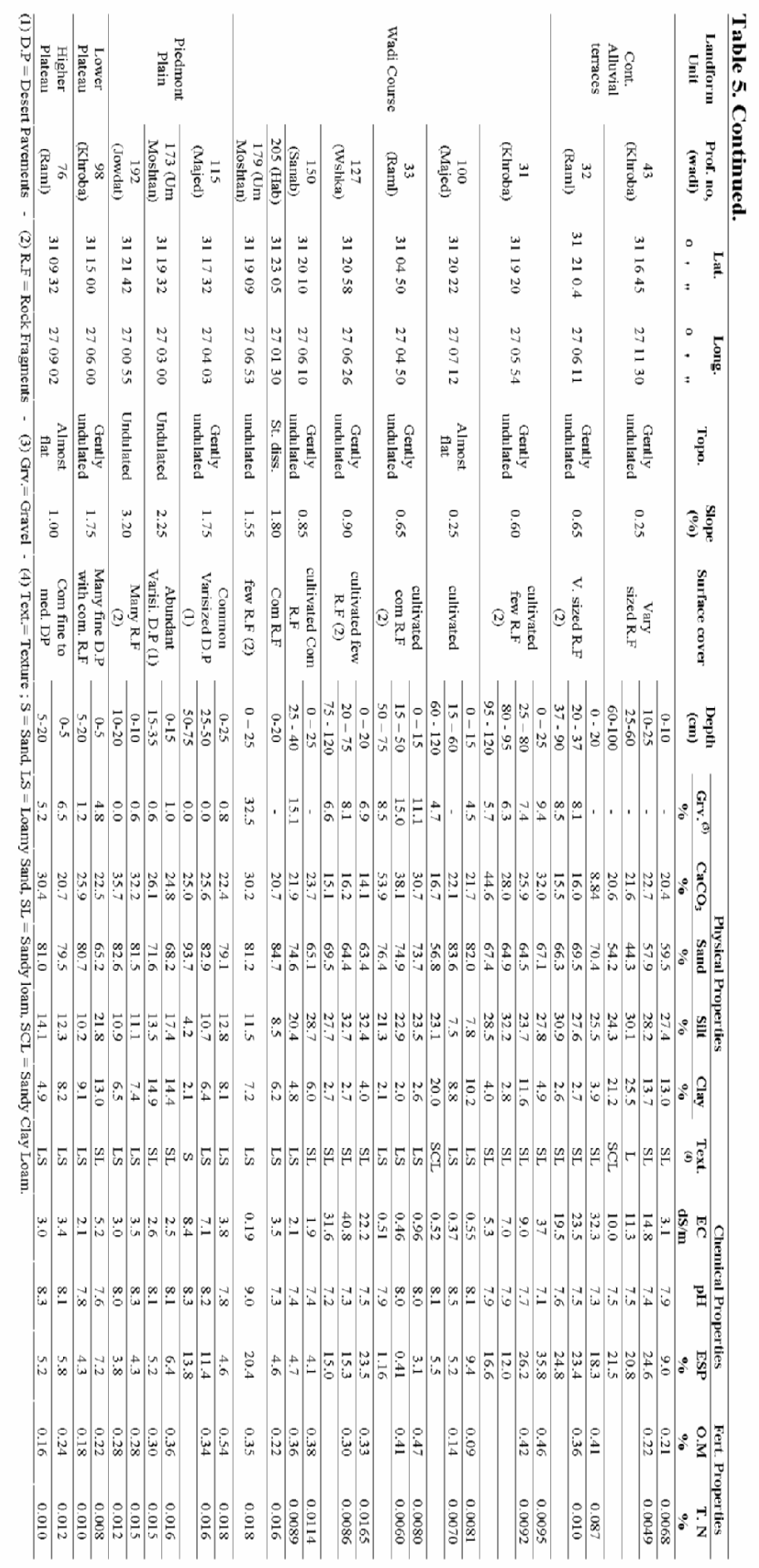


The latter could be defined as very shallow coarse textured soils with almost flat to gently undulating topography (pedons $98 \& 76$ ). On the family level, this soil is classified as Sandy, calcareous, hyperthermic; Lithic Torriorthents

In general, soils of investigated area were classified to follow one of six sub groups; Typic Torrifluvents
(24259 F - 15.2\%), Typic Torripsamments (28728 F 18.0\%), Lithic Torripsamments (36070 F - 22.6\%), Lithic Torriorthents (56978 F - 35.7\%), oolitic Torripsamments (7980 F - 5.0\%), Typic Aquisalids (5586 F - 3.5\%), and Typic Haplosalids (260 F -0.15\%) as shown in table (6) and map (7).

Table 6. Main landforms, associated soil mapping units and soil Taxa of the studied area

\begin{tabular}{|c|c|c|}
\hline Landform units & Soil Mapping Units & Soil Taxa (Family level) \\
\hline OSB \& OSD & $\begin{array}{l}\text { Shallow to deep Oolitic coarse - textured soils with } \\
\text { almost flat topography. }\end{array}$ & $\begin{array}{l}\text { Carbonatic, hyperthermic; oolitic } \\
\text { Torripsamments. }\end{array}$ \\
\hline LGSM & $\begin{array}{l}\text { Shallow to deep, med. to coarse - textured soils with } \\
\text { interlayering salts, and almost flat topography }\end{array}$ & $\begin{array}{l}\text { Coarse loamy, calcareous, } \\
\text { hyperthermic; Typic Aquisalids. }\end{array}$ \\
\hline \multirow{3}{*}{ AFN } & $\begin{array}{l}\text { (1) Deep moderately coarse to coarse- textured soils, } \\
\text { sometimes with finer surface or substratum and } \\
\text { almost flat topography, }\end{array}$ & $\begin{array}{l}\text { (1) Coarse loamy, calcareous, } \\
\text { hyperthermic; Typic Torrifluvents, }\end{array}$ \\
\hline & $\begin{array}{l}\text { (2) Deep coarse textured - soils with almost flat to } \\
\text { gently undulated topography, }\end{array}$ & $\begin{array}{l}\text { (2) Calcareous, hyperthermic; Typic } \\
\text { Torripsamments. }\end{array}$ \\
\hline & $\begin{array}{l}\text { (3) Moderately deep moderately coarse to coarse - } \\
\text { textured soils with almost flat to gently undulating } \\
\text { topography. }\end{array}$ & $\begin{array}{l}\text { (3) Fine loamy, calcareous, } \\
\text { hyperthermic; Typic Torrifluvents }\end{array}$ \\
\hline \multirow{5}{*}{ AT - IW } & $\begin{array}{l}\text { (1) Deep moderately coarse to coarse- textured soils, } \\
\text { sometimes with finer surface or substratum and } \\
\text { almost flat to gently undulating topography, }\end{array}$ & $\begin{array}{l}\text { (1) Fine loamy, calcareous, } \\
\text { hyperthermic; Typic Torrifluvents, }\end{array}$ \\
\hline & $\begin{array}{l}\text { (2) Deep coarse textured - soils with almost flat to } \\
\text { gently undulated topography, }\end{array}$ & $\begin{array}{l}\text { (2) Calcareous, hyperthermic; Typic } \\
\text { Torripsamments, }\end{array}$ \\
\hline & $\begin{array}{l}\text { (3) Moderately deep moderately coarse to coarse - } \\
\text { textured soils with almost flat to gently undulating } \\
\text { topography, }\end{array}$ & $\begin{array}{l}\text { (3) Coarse loamy, calcareous, } \\
\text { hyperthermic; Typic Torrifluvents, }\end{array}$ \\
\hline & $\begin{array}{l}\text { (4) Shallow moderately coarse to course - textured } \\
\text { soils with almost flat to undulating topography, }\end{array}$ & $\begin{array}{l}\text { (4) Calcareous, hyperthermic; Lithic } \\
\text { Torripsamments, }\end{array}$ \\
\hline & $\begin{array}{l}\text { (5) Very shallow coarse - textured soils with } \\
\text { undulating topography. }\end{array}$ & $\begin{array}{l}\text { (5) Sandy, calcareous, hyperthermic; } \\
\text { Lithic Torriorthents. }\end{array}$ \\
\hline \multirow{4}{*}{ WCRS } & $\begin{array}{l}\text { (1) Deep moderately coarse to coarse- textured soils, } \\
\text { sometimes with finer surface or substratum and } \\
\text { almost flat to gently undulating topography, }\end{array}$ & $\begin{array}{l}\text { (1) Coarse loamy, calcareous, } \\
\text { hyperthermic; Typic Torrifluvents, } \\
\text { (1) Coarse loamy, calcareous, } \\
\text { hyperthermic; Typic Haplosalids, }\end{array}$ \\
\hline & $\begin{array}{l}\text { (2) Moderately deep moderately coarse to coarse - } \\
\text { textured soils, with gently undulating topography, }\end{array}$ & $\begin{array}{l}\text { (2) Carbonatic, hyperthermic; Typic } \\
\text { Torripsamments, }\end{array}$ \\
\hline & $\begin{array}{l}\text { (3) Shallow coarse - textured soils, with gently } \\
\text { undulating topography. }\end{array}$ & $\begin{array}{l}\text { (3) Calcareous, hyperthermic; Lithic } \\
\text { Torripsamments, }\end{array}$ \\
\hline & $\begin{array}{l}\text { (4) Very shallow coarse - textured soils, with } \\
\text { undulating to steeply dissected topography. }\end{array}$ & $\begin{array}{l}\text { (4) Sandy, calcareous, hyperthermic; } \\
\text { Lithic Torriorthents. }\end{array}$ \\
\hline \multirow{3}{*}{ PDP } & $\begin{array}{l}\text { (1) Moderately deep coarse texture soils with gently } \\
\text { undulated topography, }\end{array}$ & $\begin{array}{l}\text { (1) Calcareous, hyperthermic; Typic } \\
\text { Torripsamments, }\end{array}$ \\
\hline & $\begin{array}{l}\text { (2) Shallow moderately coarse to course - textured } \\
\text { soils with almost flat to undulated topography, }\end{array}$ & $\begin{array}{l}\text { (2) Coarse loamy, calcareous, } \\
\text { hyperthermic; Lithic Torriorthents, }\end{array}$ \\
\hline & $\begin{array}{l}\text { (3) Very shallow or rocky coarse - textured soils with } \\
\text { undulated topography. }\end{array}$ & $\begin{array}{l}\text { (3) Sandy, calcareous, hyperthermic; } \\
\text { Lithic Torriorthents. }\end{array}$ \\
\hline PL & $\begin{array}{l}\text { Very shallow or rocky coarse textured - soils with } \\
\text { almost flat to gently undulated topography. }\end{array}$ & $\begin{array}{l}\text { Sandy, calcareous, hyperthermic; } \\
\text { Lithic Torriorthents. }\end{array}$ \\
\hline
\end{tabular}




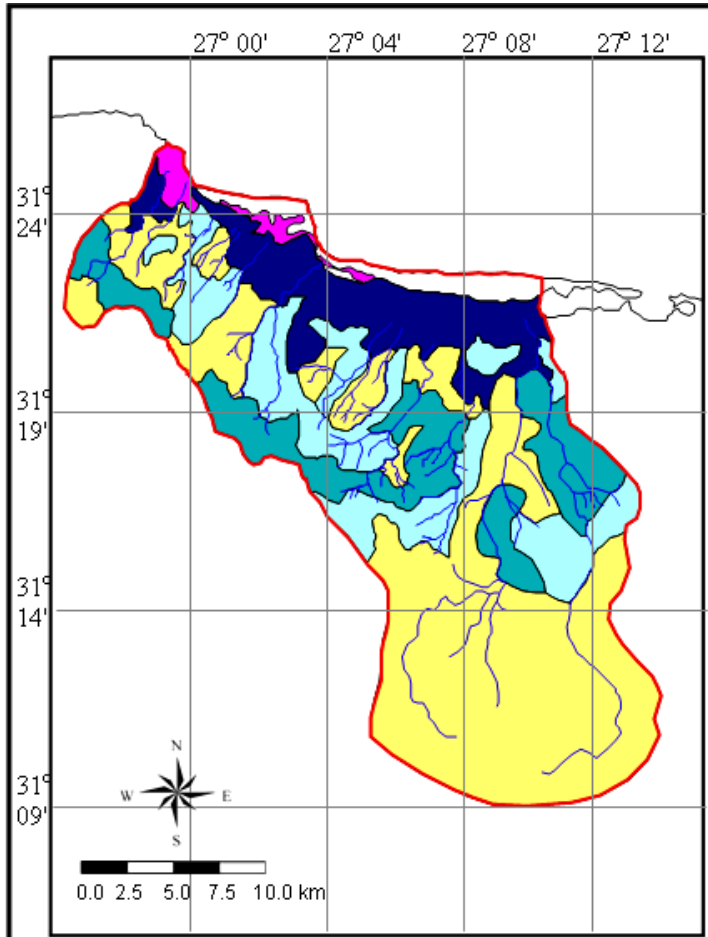

Typic Torrifliwents $\quad \mathbf{1 5 . 2 \%}$

$\square$ Typic Torripsamments $\mathbf{1 8 . 0 \%}$

$\square$ Lithic Torripsamments $\quad 22.6 \%$

$\square$ Lithic Torriorthents $\quad \mathbf{3 5 . 7 \%}$

$\square$ Oolitic Tompsamments $\mathbf{5 . 0 \%}$

Typic Aquisalids $\quad 35 \%$

\section{Map 7. Soil Taxa of the studied area.}

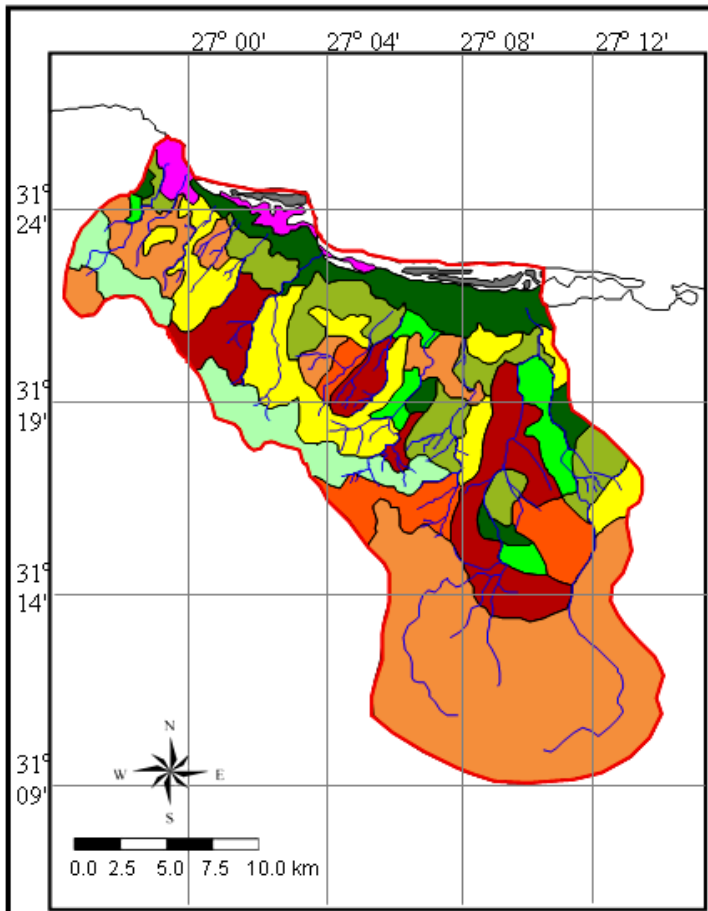

Deep mod. coarse to coarse text.- soils sometimes with finer surface with almost flat topography (AFN), (AT- IW), (WCRS).

Deep coarse text.- soils with almost flat to gently undulated topography (AFN), (AT IW)

Mod. deep mod. coarse to coarse text. soil

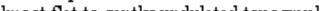
(AFN), (AT- IW), (WCRS)

Mod. deep coarse text. soils with gently undulated topography (PDP)

$9.2 \%$ Shallow mod. coarse text. soils with almost (PDP)

Shallow coarse te xt soils with gently undulated topography (WCRS), (PDP),

Very shallow or rocky coarse text. soils with $\mathbf{2 4 . 4 \%}$ almost flat to gently undulated topography (AT- IW), (PL)

Very shallow or rocky coarse text soils with $113 \%$ undulated topography (WCRS), (PDP), (ATIW

Shallow to deep Oolitic coarse text. soils with almost flat topography (OSB)

Oolitic coure text sols of conplex $2.2 \%$ longitudinal dunes (OSD)

Shallow to deep med. to coarse text. soils with interlayering salts with almost flat with interlayering sals

Map 8. Soil Mapping Units in the studied area. 


\section{2- Land potentiality classification}

Soils of different landforms were evaluated to assess their potentiality for rainfed agriculture. Potentiality indices and classes were calculated as shown in table (7) and map (9). Further, limitations of each soil potentiality class were identified. Five potentiality classes were differentiated; Good (21706 feddan 13.6\%) - Fair (31282 feddan - 19.6\%) - Poor $(36070$ feddan $-22.6 \%)$ Very Poor (61447 feddan - 38.5\%) Non agriculture (9097 feddans - 5.7\%)

\section{Good soil potentiality}

Soils of this unit are characterized as: (1) deep moderately coarse to coarse- textured soils sometimes with finer surface or substratum with almost flat to gently undulating topography, or (2) Deep coarse textured - soils with almost flat to gently undulated topography. They are formed on alluvial fans, alluvial terraces and interfluves wadis, and lower portions of wadi courses. Soils of this class have the most suitable conditions as their potentiality index ranges between $60.9-68.1 \%$. The potentiality index varies in relation to differences in soil taxa. The higher value is mainly associated with soils belonging to the soil families Fine loamy or coarse loamy, calcareous, hyperthermic; Typic Torrifluvents. They are followed by soil families Calcareous, hyperthermic; Typic Torripsamments, and Coarse loamy, calcareous, hyperthermic; Typic Torrifluvents. Meanwhile, soil family Coarse loamy, calcareous, hyperthermic; Typic Haplosalids has shown the lower values. These soils display moderate constraints related to the low clay content and low fertility status, in addition to sever salinity located in some scattered patches in the down streams where soils are irrigated supplementary with rather saline shallow well water. Orchards of fig, olive as well as some vines and almond trees are the dominant which were interpolated with some vegetables like tomato, piper and cantaloupe. Field winter crops like barley and wheat are cultivated sometimes in scattered rainfed patterns.

\section{Fair soil potentiality}

This unit includes soil types (1) moderately deep moderately coarse to coarse - textured soils with almost flat to gently undulating topography which formed within the alluvial fans, alluvial terraces and interfluves wadis and middle portions of wadi course landforms, and (2) moderately deep coarse - textured soils with gently undulating topography which formed on piedmont plain. Soils in this unit have potentiality index ranges between 42.5 and $57.0 \%$, reflecting fair soil potentiality. They are belonging to the family Coarse loamy, calcareous, hyperthermic; Typic Torrifluvents and have the higher values followed by soils belonging to Calcareous, hyperthermic; Typic Torripsamments. Whereas, soils belonging to the family Carbonatic, hyperthermic; Typic Torripsamments have shown the lower conditions. Soil limitations include moderate effective soil depth, imperfect drainage, low available water and low fertility status. These soils are plowed for rainfed barely and wheat in addition to vegetables, i.e. tomato, piper and cantaloupe. Most of the wadi courses especially at down streams are fully occupied by fig and olive trees, among which vegetables are interpolated. Some scattered areas in this unit are supplementary irrigated by ground water. As lots of cemented and / or stony dykes are established between different levels along the streams for water harvesting (DRC, 2013).

\section{Poor soil potentiality}

Such class of potentiality includes the shallow soils belonging to subgroups Lithic Torriorthents and Lithic Torripsamments. Particularly, poor potentiality exists over mapping units (1) shallow moderately coarse textured soils with almost flat to undulating topography, and (2) shallow coarse - textured soils with gently undulating topography. As they are formed on the piedmont plain, wadi courses and alluvial terraces and interfluves landforms. Their potentiality index ranges from 30.5 to $36.8 \%$. They display very sever limitations concerning with the limited root zone affected by the soil shallowness due to the appearance of limestone bedrock, very low clay content and low fertility status. These soils are suggested to be cultivated by barely and wheat crops under rainfed system.

\section{Very poor or non-agriculture potentiality}

Soils having very low or non-agriculture potentiality classes include the following soil units: (1) very shallow coarse - textured soils with undulating topography, formed on the upper portion of wadi courses and the piedmont plain, (2) rocky and very shallow coarse textured soils with almost flat to gently undulated topography formed on the plateau and alluvial terraces and interfluves wadis, (3) shallow to deep Oolitic coarse - textured soils with almost flat topography formed on the beach sand, (4) oolitic coarse textured soils of complex longitudinal dunes, (5) shallow to deep medium to coarse - textured soils with interlayering salts with almost flat topography formed in the Lagoon depressions and salt marshes. From which, soils belonging to soil families sandy, calcareous, hyperthermic; Lithic Torriorthents and carbonatic, hyperthermic; oolitic Torripsamments, have potentiality index ranges from 10.2 to $11.5 \%$ and their potentiality classified as very poor. 


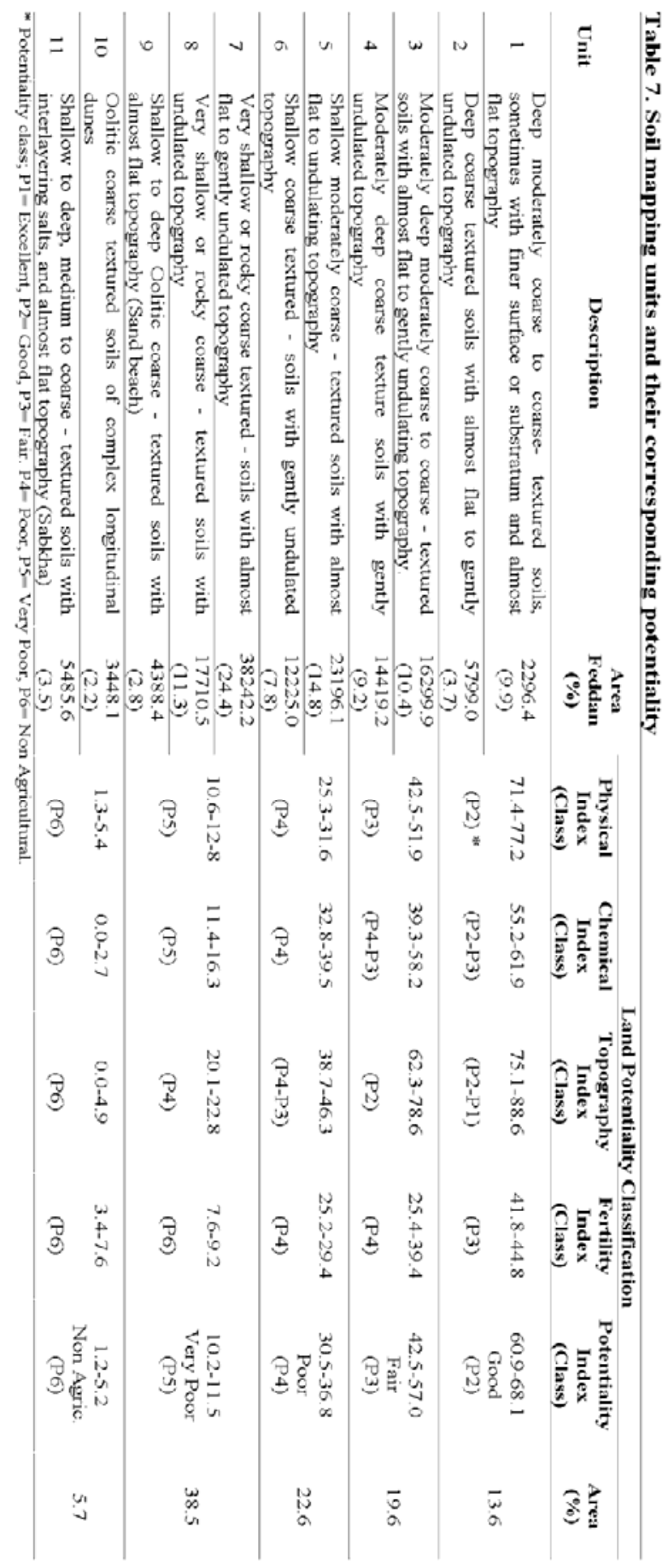




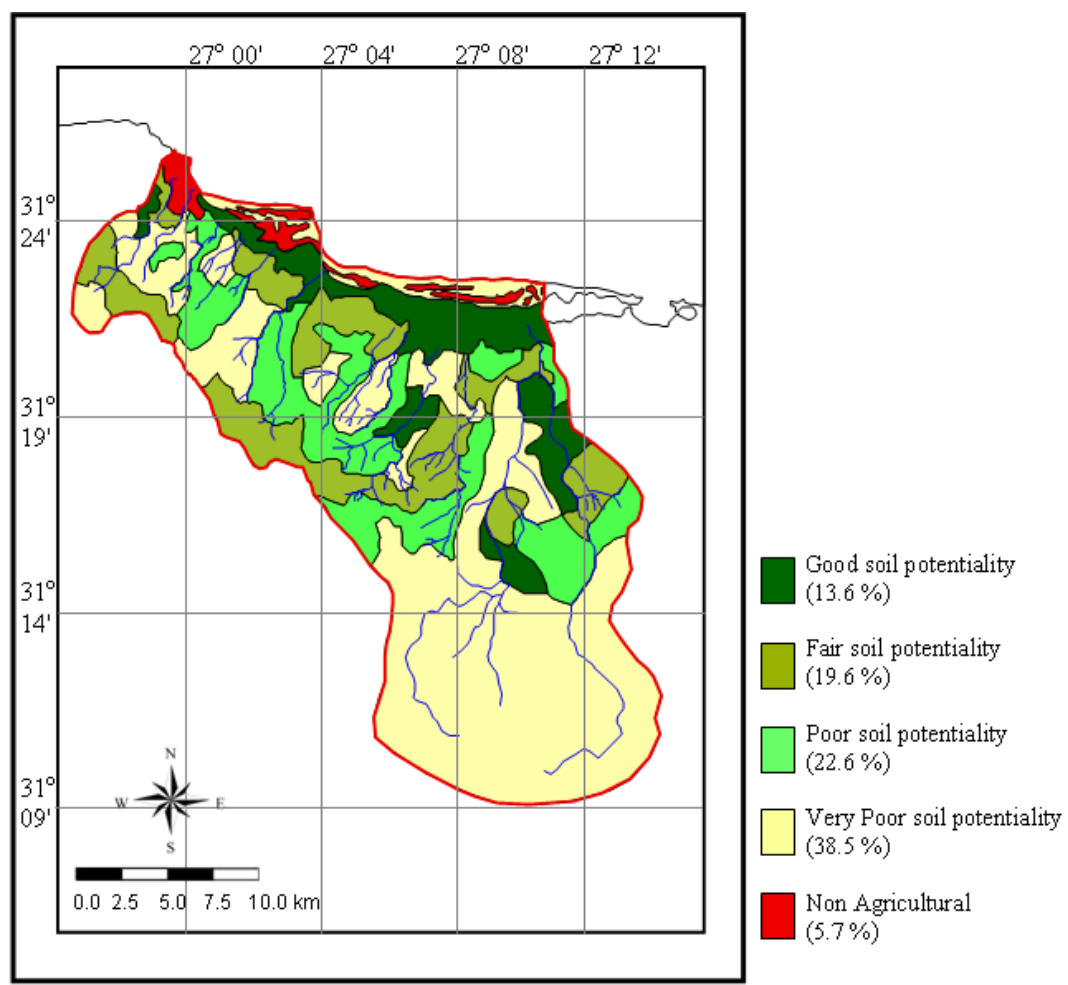

Map 9. Soil potentially in the studied area.

Meanwhile, Soils belong to soil families coarse loamy, calcareous, hyperthermic; Typic Aquisalids and Carbonatic, hyperthermic; oolitic Torripsamments have potentiality index varied from 1.2 to $5.2 \%$, therefore they are classified as non-agriculture soils. These units have various very severe constraints, i.e. very limited effective root zone, very poor drainage, very coarse texture, extreme high carbonates, sever high salinity and very poor soil fertility. Thus, they are considered non useful from agricultural point of view, meanwhile, could be relevant to other land utilization types.

\section{REFERENCES}

Abdel-Kader, F.H. and H.M. Ramdan. 1994. Land Evaluation of Dabaa-Fuka Area, North-Western Coast, Egypt Using Geographical Information System (GIS). Egypt. J. Soil Sci., 35 (2): 203-214.

Abdel-Kader, F.H. and J. Fitz Simon. 2002. Participatory Land and Water Management in Dryland Agropastoral Areas. NW Coast of Egypt. Final Report, Department of Soil and Water Sciences, Faculty of Agriculture, Univ. of Alexandria, Egypt.

Abdel-Kader ,F. H. ; J. Fitzsimons ; M. Bahnassy and A. Moustafa. 2004. Challenges in Resource Management in Rainfed Agriculture in Wadi Naghamish, North Western
Coastal Region, Egypt. Egyptian J. Desert Res., 54, No.2, 237-258

Abd El-Rahman, S. M. H., Y. S. Kasim and H. A. El-Attar. 1986. Soils of North Western Coastal Region in Land Use Classification. Egypt. J. Soil Sci., (Special Issue) pp. 1728.

Abd El-Rahman, S. M. H., Y. S. Kasim and H. A. El-Attar. 1987. Soil Taxa of North Western Coastal Region of. Egypt. J. Soil Sci., (27) No. 1, pp. 11-29.

Abu El-Izz, M. S. 1971. Landforms of Egypt, John Wiley and Sons, New York.

DRC Staff. 2007-2015. Integrated Agriculture Development of Northwestern coastal wadies. Annual report. Desert Research Center publications.

EGPC. 1988. Egyptian General Petroleum Corporation: Geological Map of Egypt, Sheets NH36-NW, "Cairo", Conoco Coral, printed in Germany by institute fur Angewandte Geodasie, Berlin, (c) Technische Fachhochschule Berlin, 1988, Scale 1:500,000.

El-Shazely, E. M., M. A. Abdel Hady, and M. A. ElGhawaby. 1975. Geologic interpretation of LANDSAT satellite images for west Nile Delta area, Remote sensing research project. Academic of scientific research and tecknology, Cairo, Egypt.

ESRI. 2006. Arc-GIS user manual. Version 9.2. Redlands. California. 
FAO. 1970. Pre investment survey of the northwestern coastal region. ESE : SF/UAR 49

FAO. 1983. Guidelines: Land evaluation for rainfed agriculture. FAO soil Bulletin, No. 52, FAO, Rome.

FAO .2006. Guidelines for soil profile description. 4th ed., FAO Publications, Rome.

Harga, A.A. and F. A. Rabie. (1974) The classification of the soil of the Mediterranean coastal littoral into the 7 th Approximation. J. Soil Sci., Egypt. 14 (2), 177.

IMAGINE 8.6. 2001. Geographic imagine package. ERDAS Inc. USA.

Ismail, H. A., S. M. H. Abd El-Rahman and F. H. Abd ElKader (1986) Pedological study of Omayed toposequence northwestern Mediterranean desert of Egypt. Cash ORSTOM, vol. XXII, no. 1, 63-76.

Jackson, M.L. 1973. Soil chemical analysis. Advanced course Ed.2. A Manual of methods useful for instruction and research in soil chemistry, physical chemistry of soil, soil fertility and soil genesis. Revised from Original Edition (1955).

Khalifa, M. E. A. 2004. An Integrated Parametric Evaluation Model for Land Resource Management: A Case Study for El-Bostan Extension Sector, West Nubaria , Egypt. Ph.D
Thesis, Soil \& Water Dept., Faculty of agriculture, University of Alexandria, Egypt.

Khalifa, M. E. A. 2013. Terrain Analysis as a Criterion for Soil Attributes at Wadi Al-Shobeity, Northwestern Coast, Egypt. Alexandria Science Exchange J., Vol. 34, No.4.

Page, A. L., R. H. Miller, and D. R. Keeny. 1982. Methods of Soil Analysis, Part 2- Chemical and Microbiological Properties. Agronomy Monograph No. 9. ASA, SSSA, Madison, WI.

Shaaban, F. F. 2010. Vertical electrical sounding for groundwater investigation in northwestern Egypt: a case study in a coastal area. African Earth Sciences, (33) 673686.

Shata, A. 1971. Geomorphology, Pedology, and hydrology of the Med. coast desert of U.A.R. Symposium on the geology of Libya: 431-446. Fac. Sci, Libia A.R.

Soil Survey Staff (S.S.S). 2010. Keys to Soil Taxonomy U.S.D.A., Soil Cons. Serv., Washington, USA.

Sys, C., E. Van Ramst, and J. Debaveye, 1991. Land evaluation. Part I - Principle in land evaluation and crop production calculation. Agricultural publication - no. 7, General administration for development cooperation, Brussels, Belgium.

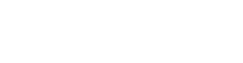

\section{قسيم لأرالف وقيمقرتها الإنتاجية لجصضمنلاق الزراعلت الملربة بغرب طلرح - اللسالل الثمالل الغرى المصر \\ محمد عزت عبد الهادى خلفة ونول فخرى بشاى الفيال}

بالمطقة بلِيتخدالم الخرائط الجيومورفولوجية والطبوغرافية

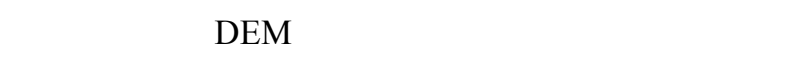

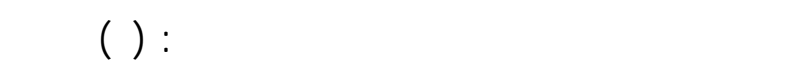

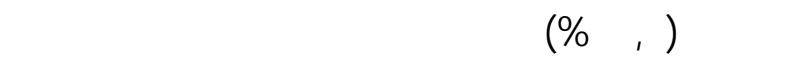

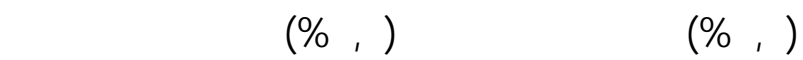

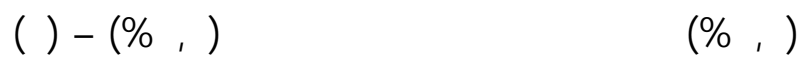

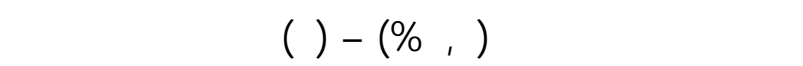

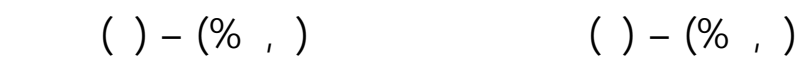

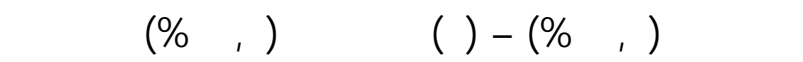

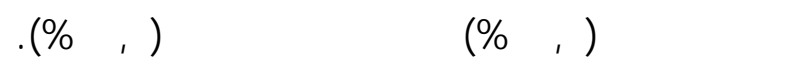

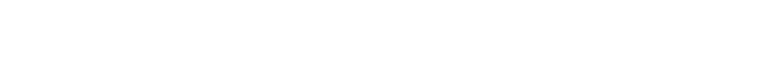

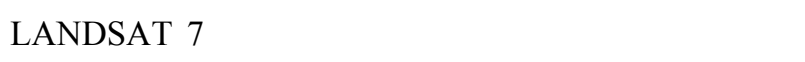

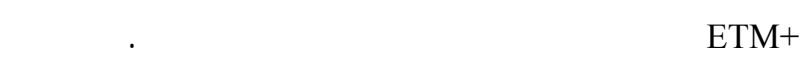

إن تنمية الأقاليم الصحراوية تع ــ أه م أدوات الدول ـة

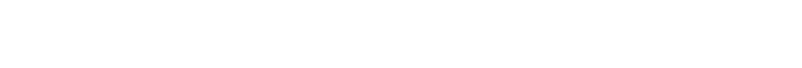
لمصر فى مقدمة المنطق الصحراوية الواعدة للإست ـصلاح

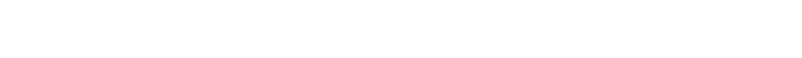

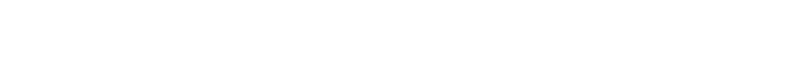

وقد لجرى هذا البحث بهذف تحديد أن _واع الأراض ق

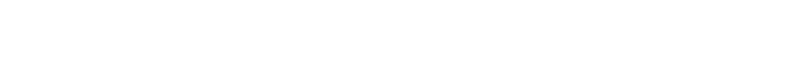

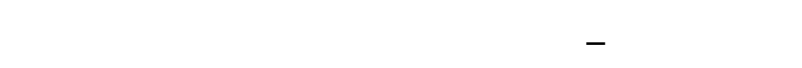

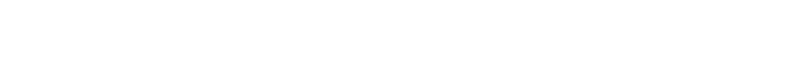
قرارات الإستصلاح بالمطقة . حيث تمتد مطق ـة الدرلس ــة

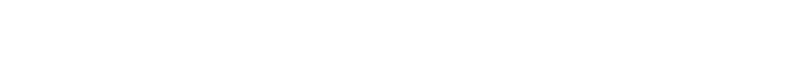
مائع. مُ تحديد التوزيع المكانف للأشكل الأرضية الـ سائكة 
الطبوغرافية ذات اللططوح المستوية قريبا إلى هينة التموج على ب,\% \% من إجمالى المسلحة.

واققد خلصت الدرلسة إلى تصنف قدرة التربة الإنتلجية

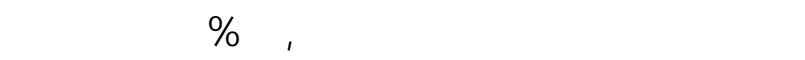

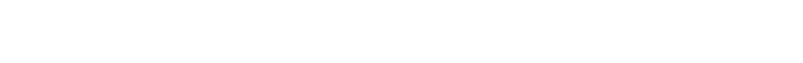

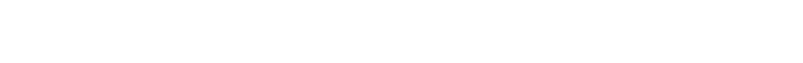

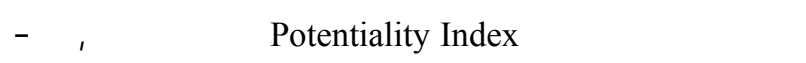
171,1

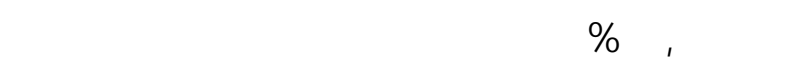
المراوح الرسوبية والمصطب الوسوبية والأجزاء الوسطى

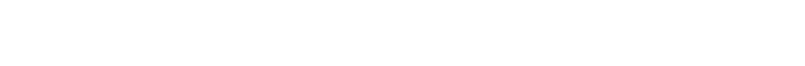
ما بين O Potentiality Index التربة الإنتاجية الفقيرة على مسلحة 7,7r\% من إجم اله له

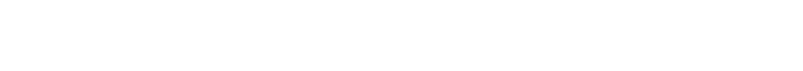
الرسوبية والأجزاء العليا لمجارى الأونية وللسهل التحاتق،

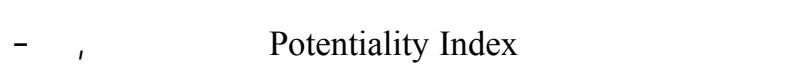

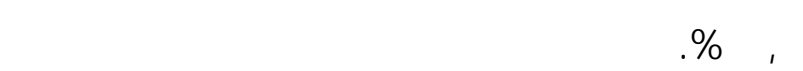
صالحة للإستغلال الزراعى حيث تحف دليل القدرة الإنتلجية

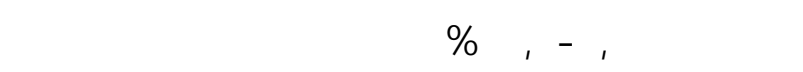

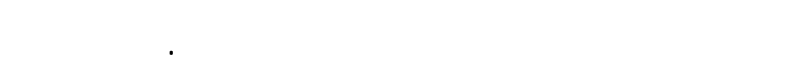

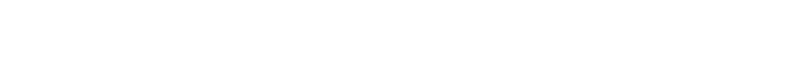

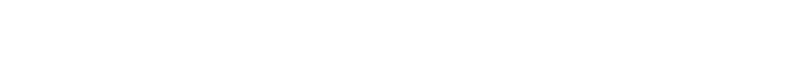
الصرف، قولم التربة الخشن وقص المكون الطين، إرتفاع نسب الجير والملوحة، الفقر فى خصوبة التربة.
على الدرلسلت الققلية والمعملية لمك نـ نق سيم أراض ق المطقة على مستوى العائلة Soil Family إلى ع عدد ( · ( )

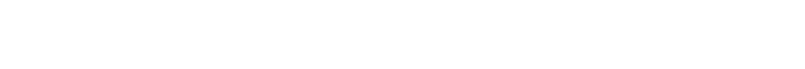
قuمت لتتع لحسبع تحت مجلمبع كبرى Sub Great group

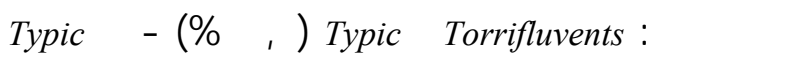
Lithic Torripsamments - $(\%) \wedge, \cdot)$ Torripsamments Typic - $(\% \mathrm{w}, \mathrm{V})$ Lithic Torriorthents - $(\% \mathrm{r}, \mathrm{7})$ Oolitic Torripsamments - $(\% \mathrm{\%}, 0)$ Aquisalids Typic Haplosalids - $(\% 0, \cdot)$

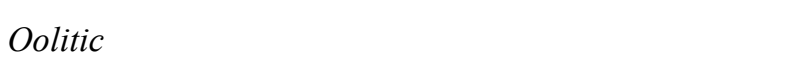
Typic Torripsamments Aquisalids تحت مجموعة Typic Torrifluvents ولأحيانا إل م Torripsamments

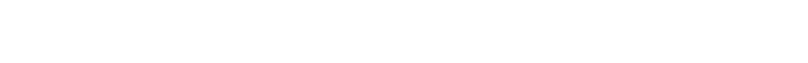

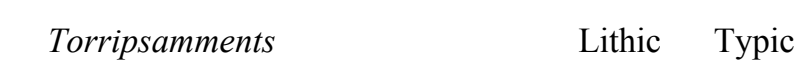
Torriorthents ، ولحيانا ما قسمت مسلحكت محدووة منها إلى

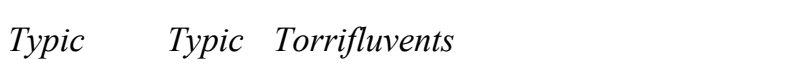

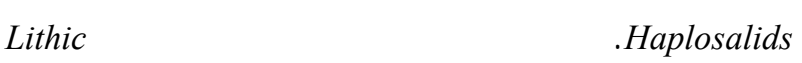
.Torriorthents وبناءا على صفلت عمق التطاع الأرضى وقولم الترب ـة وطبوغرافية للسطح قسمت أراض المطقة لع دد ء ششرة

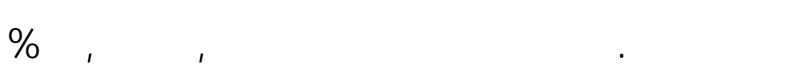

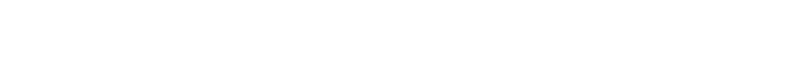

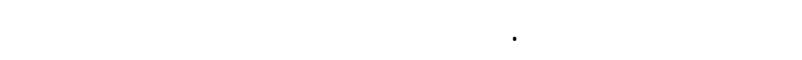

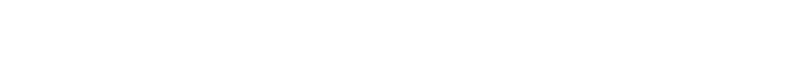

